\title{
Foreign Language Teaching Reform in China Higher Education from "Culture Aphasia" Perspective
}

\author{
Cai-qiao Huo ${ }^{1, \text { a }}$, Xiao-mei $\mathrm{Du}^{2, \text { b }}$ \\ ${ }^{1}$ Foreign Language Department,Baoding University,Baoding, China \\ ${ }^{2}$ Foreign Language Department, Baoding University Baoding,china \\ a150095119@qq.com, bgoofyhuo@163.com
}

\begin{abstract}
Culture is a result of the accumulation of human society, language is the important carrier of culture. Infiltration of western culture and the widely used of English, seriously hindered the globalisation of the Chinese culture, the resulting "cultural aphasia" phenomenon. As the main place of cultivating high-level talents in colleges and universities, how to use the foreign language teaching reform to change the status quo, is becoming a hot research. This paper first has carried on the outline of "cultural aphasia" phenomenon, and then analyzed the reasons, finally proposed the improvement opinions and suggestions.
\end{abstract}

Keywords: culture aphasia, teaching reform, higher education, cross-cultural communication

\section{Introduction}

Culture is an important tradition heritage and a sign of the national cultural differences, it is with the development of human society, forms through the accumulation of ideology with the regional characteristic. Language is an important communication tool, it is the main carrier of human civilization be able to save and inherit. There is an intimate relationship between language and culture, both influence and restraining each other. On the one hand, language reflects the culture of a nation, it is the power of culture to survive; on the other hand,On the other hand, culture's life is spread, especially in the cross-cultural communication, new words and expressions in language restrict the development of culture. As China's comprehensive national strength has increased, triggered a boom about learning Chinese traditional culture, more and more western scholars even civilians join in it. But English as a world language, how to realize the Chinese traditional culture to the world ? It has become a new challenge for the Chinese scholars.

"Aphasia" originally refers to these people who loss the brain damage expression ability, language expression ability and writing ability, due to injury or disease [1]. In 2000, a scholar named Congcong brought aphasia from the medical field into the foreign language teaching research for the first time, he pointed out that the Chinese scholars, who engaged in foreign language teaching, is difficult to deal with Chinese traditional culture when they made a conversation with foreigners, also he proposed that foreign language education should establish a national cultural identity, make a balance of English cultural assimilation[2]. "Cultural aphasia" phenomenon not only hindered cross-cultural communication, but also restricted the local outstanding cultural transmission[3]. Therefore, in order to realize the Chinese culture to go out, it is necessary to find out the cause of "cultural aphasia" phenomenon and solved.

Colleges and institutions as the main place to cultivate high-level, high-quality talents, foreign language teaching are the key to improve their ability, no matter for English majors or non-english major students. In cross-cultural communication, higher talents play a role as cultural exchange ambassadors, so how to make our culture better and further? It should integrate the local culture of learning in the process of foreign language teaching .

In this paper, it has carried on the outline of "cultural aphasia" phenomenon firstly, and then analyzed the reasons, some improvement suggestions are given finally.

\section{Reasons of Culture Aphasia Phenomenon}

\subsection{Historical reason}

Since modern times, western culture in a dominant position in the world, it is the symbol of the advanced culture, on the contrary, chinese culture is the representative of backward culture.In the exchange between east and west, chinese culture is largely influenced by western culture and even lost its voice on the world cultural exchange platform.

\subsection{Economics reason}

Powerful economic strength is a strong support in the development of culture, the western countries carried out the "cultural conquest" around the world, by selling its life style and ideology, some people blind pursuit of western 
culture and look local culture as vulgar, cultural aphasia phenomenon is inevitable occurred.

\subsection{Political reason}

Policy reason mainly refers to the policy orientation is not clear. In 2007, the Ministry of Education issued the College English Curriculum Requirements, it stipulated that the main content of college english teaching should be including english language knowledge and application skills, cross-cultural communication and learning strategy. In spite of this, it still lack of the cross-cultural communication definition, at the same time, it only need to translate China's national conditions and culture introduction simply, and without any other requirements for Chinese culture about other abilities. The mistaken orientation of the teaching requirements makes a vast of teachers and students believe that foreign language teaching in colleges and universities is the import of foreign culture nor native culture, so they pay more attention to guide students to learn western customs ,habits and values etc, ignore the important of local culture input. In addition, we used a lot of foreign raw materials in textbook arrangement(table 1 shown as follows with freshman and graduate textbook respectively), few of these about Chinese traditional culture introduction, although it may help to improve thinking ability, a lack of local culture vocabulary has caused among students.

Table 1. proportion of the two culture information input in the textbook

\begin{tabular}{|c|c|c|c|c|c|c|c|c|c|}
\hline Names & $\begin{array}{c}\text { Total } \\
\text { text }\end{array}$ & $\begin{array}{c}\text { Western } \\
\text { culture }\end{array}$ & Proportion & $\begin{array}{c}\text { Chinese } \\
\text { culture }\end{array}$ & Proportion & $\begin{array}{c}\text { Culture } \\
\text { comparison }\end{array}$ & Proportion & Others & Proportion \\
\hline English & 40 & 35 & $87.5 \%$ & 0 & - & 5 & $12.5 \%$ & 0 & - \\
\hline $\begin{array}{c}\text { Advanced } \\
\text { English }\end{array}$ & 60 & 50 & $83.3 \%$ & 3 & $5 \%$ & 5 & $8.3 \%$ & 2 & $3.3 \%$ \\
\hline
\end{tabular}

\subsection{Partial understanding of cross-cultural communication}

Authors submitting a manuscript do so on the understanding that if the manuscript is accepted for publication, copyright for the article, including the right to reproduce the article in all forms and media, shall be assigned exclusively to the Publisher.For a long time, the foreign language teaching practice simply attaches great importance to the input of the target language and its culture, ignored the output of native language and Chinese culture, so it will form a "one-sided" culture communication, combined with a lack of confidence in non-english speaking countries, they just follow western culture blindly, let alone spread out the essence of local culture.

\section{Empirical}

Baoding Uniersity is one of provincial key universities, its advantage disciplines are liberal arts, such as literature, philosophy, especially in foreign language study has achieved excellent results. Based on the university as an example, this paper makes relevant research and analysis with questionnaire method among English majors and non-english major undergraduate, master's graduate students respectively. This study involved in the investigation of a total of 100 students, including 60 foreign language majors and 30 graduate students, not foreign language majors in 40 and 20 graduate students. There are totally 100 copies questionnaires, 98 effective questionnaires were taken back, the recovery rate of $98 \%$.

\subsection{The situation of student to grasp Chinese traditional culture}

There are 50 topic in the questionnaire about Chinese traditional culture and it covers all aspects of traditional culture as much as possible. each question got 2 points, if right ,2 points, or else zero. From questionnaire score results, we may reached that non-english major undergraduate students for low-scoring, English major graduate serves the highest. The following are shown in table 2.

Table2. the situation of English major and non-english major students master Chinese traditional culture

\begin{tabular}{|l|l|l|l|l|l|}
\hline $\begin{array}{l}\text { Students } \\
\text { category }\end{array}$ & $\begin{array}{l}\text { English major } \\
\text { undergraduates }\end{array}$ & $\begin{array}{l}\text { English major } \\
\text { graduate } \\
\text { students }\end{array}$ & $\begin{array}{l}\text { Non-English major } \\
\text { undergraduates }\end{array}$ & $\begin{array}{l}\text { Non-English major } \\
\text { graduate students }\end{array}$ & The average \\
\hline Scoring rate & $72.5 \%$ & $78.9 \%$ & $60.7 \%$ & $68.9 \%$ & $70.25 \%$ \\
\hline
\end{tabular}

3.2 Chinese traditional culture curriculum and the status of the classroom teaching

In the questionnaire, students are required to select the most closely related species about Chinese traditional culture (at least 5 course) and write down, in addition, whether there is a teacher to guide learning Chinese traditional culture or its English expression and be able to learn about Chinese traditional culture in the teaching textbook. After analysis, we found that only the English major students said the 
teacher will increase traditional culture of foreign language learning gradually as the growth of the grade, the undergraduate English majors to accept such knowledge at least. Figure 1, 2, 3 as following shown.

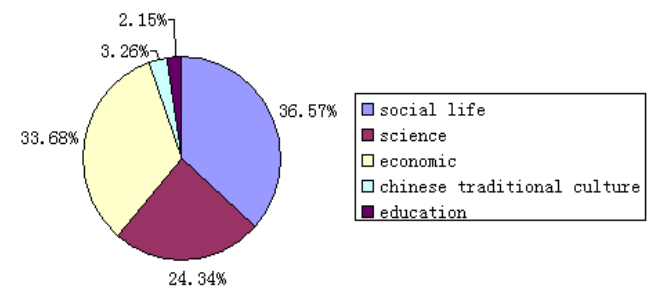

Fig.1 non-english major students teaching textbook form

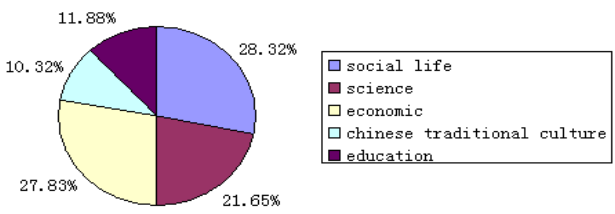

Fig.2 English majors teaching material form

rate of classroom teaching

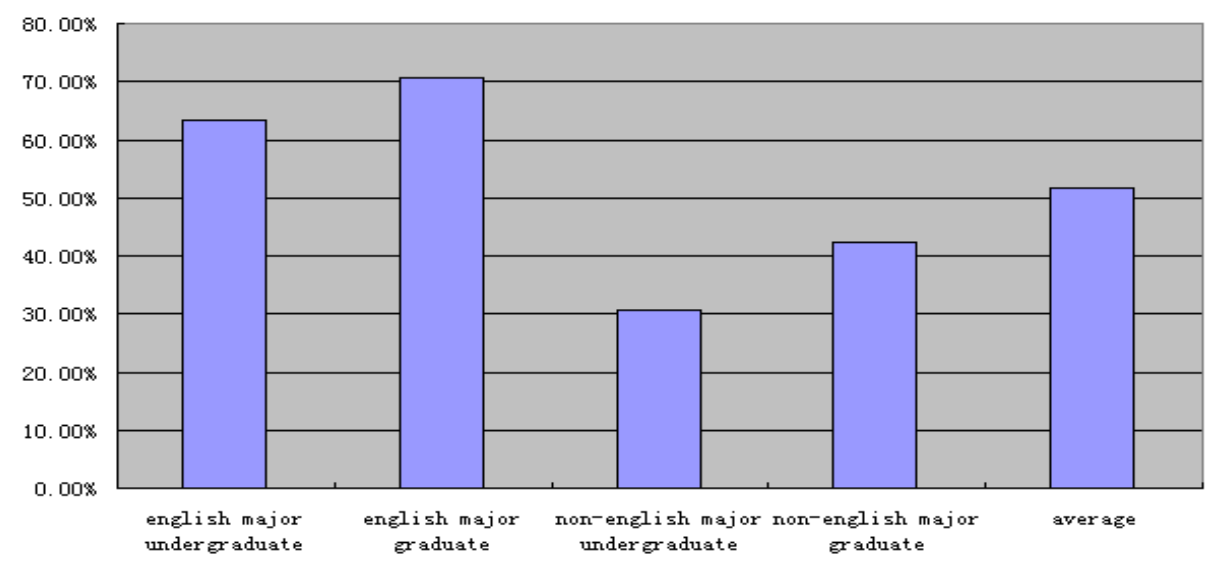

Fig. 3 foreign language expression rate of Chinese traditional culture in class

\subsection{Student's attitude to add Chinese culture in English education}

There are 5 questions in questionnaire to understand students attitude about whether join Chinese traditional culture in English teaching, more than $60 \%$ of the students think it is very necessary, only $5 \%$ think it is unnecessary, as shown in figure 4 . This suggests that students eager to know the foreign expression of Chinese traditional culture, but due to their knowledge is not ideal, caused the ability to carry forward the excellent culture of the Chinese nation is unsatisfactory.

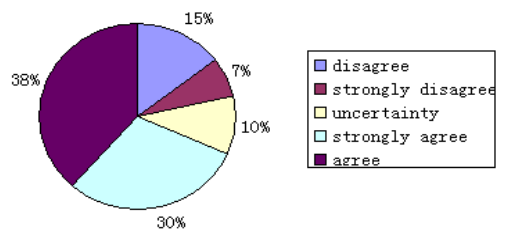

Fig.4 whether add traditional Chinese cultural knowledge in English teaching textbooks

\section{Suggestions}

With the "cultural aphasia" phenomenon has occured, more and more scholars put forward different opinions and suggestions, it may be said that "hundred flowers blooming and hundred schools contending", each one has his own point of view. But on the whole, the focus of debate is how to integrate Chinese native culture how to teach Chinese native culture teaching.

\subsection{Improve foreign language teachers native culture quality}

Foreign language teachers is the main force of foreign language teaching in colleges and universities, playing a connecting link role in spreading Chinese culture.On the one hand, foreign language teachers are professional trained in higher education of foreign language, compared to students they have a higher capacity, in terms of understanding and the understanding of western culture, so thty should take more responsibility in spreading Chinese 
culture; on the other hand, as a foreign language teaching in colleges and universities directly, it is necessary for foreign language teachers to instruct students to learn the Chinese culture into the western thinking, not only western culture teaching, in order to apply to the global spread of Chinese culture.

The foreign language teacher's own mother tongue culture quality and the teaching idea directly affects the student's learning effect, so it is imperative to improve their native culture quality. First, teachers should abandon the traditional teaching concept, fully aware of the importance and urgency of native culture in foreign language teaching, improve themselves and the students' Chinese culture accomplishment and the ability to express Chinese culture in English consciously; accumulate the English expression of Chinese culture, such as reading books, by network ,participate in academic exchanges irregularly and other different ways, aims to update existing knowledge timely and promote the communication skills.

\subsection{Gradually focus on Chinese culture in foreign language textbook arrangement}

Although there has a lot of foreign language textbook version of the higher education on the market currently, but a common phenomenon is that the selected article material originate from foreign periodicals or books and so on, few of them related to Chinese traditional culture. Students just blindly pursue how to comply with the foreign language thinking style and make the expression more authentic, but for how to use language to express Chinese traditional culture is especially lacking, let alone use, "cultural aphasia" phenomenon is unavoidable. Therefore, on the teaching material arrangement should consciously increase about the original foreign language of Chinese traditional culture, it not only can make students learn authentic language expression, but also can guide students to set up the correct cultural values, mobilize $s$ their interest in initiative to explore Chinese traditional culture.

\subsection{Cultivate students' sense of national pride, strengthen intercultural communication}

The Chinese nation is the long history of nation, Chinese culture has a long history, cultivate the students' sense of national pride, enhance national self-confidence, to improve the "cultural aphasia" is also very beneficial[4]. Intercultural communication is an important way of culture "bring in" and "go out", it can learn foreign advanced culture as well as introduce chinese outstanding culture to all over the world, to understand the differences between cultures. Along with China plays a more and more important role in the international arena, more and more western scholars are keen to study Chinese traditional culture, so a successful intercultural communication is not simply cultural single input, local culture output more and more is needed.

\section{Conclusion}

Native culture teaching foreign language teaching integral part of culture, and in the context of global cultural exchange, only equal, two-way communication is possible to achieve a win-win for effective communication.So, aiming at the phenomena of Chinese culture aphasia, foreign language teachers to train the student to the native culture and the culture of target language equality consciousness,Strengthen the education of mother tongue culture in foreign language teaching, solve the problem of the Chinese culture aphasia, this is the need of cross-cultural communication, also is the need of carrying forward the culture of the Chinese nation.

\section{References}

[1] Zhaoyan.Lack of local culture in cultural aphasia phenomenon and countermeasure research $[\mathrm{J}]$.Forward Position,2011(24):pp192-193.

[2]Hua ying. Reflecting on foreign culture teaching from aphasia of chinese culture[J].Journal of Gansu lianhe University(social sciences), 2011,26(3):pp192-193.

[3]Kramsch,C. Language and Culture[M].Oxford University Press:oxford,pp.110.1998.

[4]Longfu Xiao,Di Xiao,etc. A study of the "chinese culture aphasia" in present English education in Chinese higher education[J].Foreign language learning theory and practice, 2010(1),pp:39-47. 